\title{
PENGARUH SKARIFIKASI DAN KOMPOSISI MEDIA TERHADAP PERKECAMBAHAN DAN PERTUMBUHAN SEMAI TREMBESI (Samanea saman. Jacq)
}

\section{Effect of scarification and Composition Media the germination and Growth Trembesi seedlings (Samanea saman.Jacq)}

\author{
Achmad Valliant Ali $^{1 *}$, Amir Syarifuddin ${ }^{1}$, Joko Triwanto ${ }^{1}$ \\ ${ }^{1}$ Jurusan Kehutanan, Fakultas Pertanian-Peternakan Universitas \\ Muhammadiyah Malang Jalan Raya Tlogomas No.246, Tlogomas, Malang, Jawa Timur \\ 65144. \\ *Email : greenyplants28@gmail.com
}

\begin{abstract}
The tamarind tree (Samanea saman. Jacq) plants to absorb $\mathrm{CO} 2$ is very high, good soil water absorption and to reduce the gas concentration effectively, so that it can be used as a plant reforestation. According to Dahlan, 2010. "tamarind tree has a CO2 gas absorption is very high. A tamarind tree trunks can absorb $28.488 \mathrm{Kg}$ of $\mathrm{CO} 2$ every year with a crown diameter of 15 meters. The method used in the study is RAK, factorial, where the first factor: seed soaking treatment consists of three levels. Factor II: Composition of media consists of three levels, each repeated with three replications. So that there is $3.3 .3=27$ experimental units. Each unit contained 30 seed experiment which is then multiplied by 27 experimental units, so that there are 810 seeds. The variables used to observe is, germination power, germination rate, seedling growth, which is then analyzed uniform, if there are significant duncan's test p. 0.05 to determine differences in germination were tested. The interaction of these two factors scarification and media composition in combination A2B3 treatment with germination of $96.66 \%$. Effect of scarification and medium composition at the fastest pace treatment sprouts $A 1=7,53$ days, $B 1=6.33$ days, at most leaf number $A 1=15.13$ leaf, leaf $B 3=15.15$, the highest plant height $A 1=30,47 \mathrm{~cm}, B 3$ $=30.99 \mathrm{~cm}$, the largest rod diameter $A 1=0.496 \mathrm{~cm}, B 3=0.502 \mathrm{~cm}$, the longest root length $A 1=20.60 \mathrm{~cm}, B 3=23,70 \mathrm{~cm}$, the most severe wet weight $A 1=15,57 \mathrm{gram}, B 3=$ 10.11 grams, the heaviest dry weight $=12.70 \mathrm{~g} \mathrm{A1}, B 2=7.16 \mathrm{grams}$.
\end{abstract}

Keywords : Media planting, scarification, Trembesi (Samanea saman. Jacq)

\section{Intisari}

Pohon trembesi (Samanea saman. Jacq) tanaman yang mampu menyerap $\mathrm{CO}_{2}$ sangat tinggi, penyerapan air tanah yang baik dan mampu menurunkan konsentrasi gas secara efektif, sehingga dapat digunakan sebagai tanaman penghijauan. Menurut Dahlan, 2010. "Pohon trembesi memiliki daya serap gas $\mathrm{CO}_{2}$ sangat tinggi. Satu batang pohon trembesi mampu menyerap $28,488 \mathrm{Kg}$ gas $\mathrm{CO}_{2}$ setiap tahun dengan diameter tajuk 15 meter. Metode yang digunakan dalam penelitian adalah RAK, Faktorial, dimana Faktor I : Perlakuan perendaman benih terdiri tiga level. Faktor II : Komposisi media terdiri tiga level, masing-masing diulang dengan 3 kali ulangan. Sehingga terdapat 3.3.3 $=27$ unit percobaan. Setiap unit percobaan terdapat 30 benih yang kemudian dikalikan dengan 27 unit percobaan, sehingga terdapat 810 benih. Peubah yang digunakan untuk mengamati ialah, daya perkecambahan, laju perkecambahan, pertumbuhan semai, yang kemudian dianalisis seragam, bila terdapat 


\section{JOURNAL OF FOREST SCIENCE AVICENNIA}

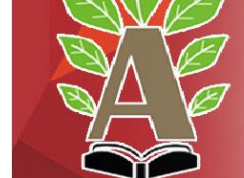

E-ISSN : 2622-8505 | Email : avicennia.kehutananumm@umm.ac.id hup://ejournal umm.ac.id/index.php/avicennia

O Jl. Raya Tlogomas No.246 Malang, Jawa Timur 0822-5785-2386 (Febri)

pengaruh dilakukan uji duncan's p. 0,05 untuk mengetahui perbedaan perkecambahan yang di uji cobakan. Terjadi interaksi dari kedua faktor skarifikasi dan komposisi media pada kombinasi perlakuan A2B3 dengan daya kecambah sebesar 96,66 \%. Pengaruh skarifikasi dan komposisi media pada laju kecambah paling cepat perlakuan $\mathrm{A} 1=7,53$ hari, $\mathrm{B} 1=6,33$ hari, jumlah daun paling banyak $\mathrm{A} 1=15,13$ daun, $\mathrm{B} 3=15,15$ daun, tinggi tanaman paling tinggi $\mathrm{A} 1=30,47 \mathrm{~cm}, \mathrm{~B} 3=30,99 \mathrm{~cm}$, diameter batang paling besar $\mathrm{A} 1=0,496 \mathrm{~cm}, \mathrm{~B} 3=$ $0,502 \mathrm{~cm}$, panjang akar paling panjang $A 1=20,60 \mathrm{~cm}, \mathrm{~B} 3=23,70 \mathrm{~cm}$, bobot basah paling berat $A 1=15,57 \mathrm{gram}, \mathrm{B} 3=10,11 \mathrm{gram}$, bobot kering paling berat $\mathrm{A} 1=12,70 \mathrm{gram}, \mathrm{B} 2=$ 7,16 gram.

Kata Kunci : Media tanam, Skarifikasi, Trembesi (Samanea saman. Jacq)

\section{PENDAhUlUAN}

Pohon trembesi atau ki hujan (Samanea saman. Jacq) adalah tanaman yang cepat tumbuh (fast growing species), mampu menyerap $\mathrm{CO}_{2}$ yang sangat tinggi, penyerapan air tanah yang baik dan mampu menurunkan konsentrasi gas secara efektif, sehingga dapat digunakan sebagai tanaman penghijauan. Menurut Dahlan "Pohon trembesi memiliki daya serap gas $\mathrm{CO}_{2}$ yang sangat tinggi. Satu batang pohon trembesi mampu menyerap 28,488 $\mathrm{Kg}$ gas $\mathrm{CO}_{2}$ setiap tahun dengan diameter tajuk 15 meter. 43 jenis pohon yang sering dimanfaatkan sebagai tanaman penghijauan. Hasilnya paling banyak menyerap karbondioksida dan memiliki kemampuan menyerap air tanah yang paling kuat" (Dahlan, 2010).

Menurut Lubis, Melya, \& Afif, 2014, "Pembudidayaan pohon trembesi memiliki kendala dalam hal perkecambahan karena kulit benih yang keras, sehingga perlu perlakuan khusus sehingga benih lebih mudah berkecambah seperti perendaman air panas $60^{\circ} \mathrm{C}$ lama perendaman 72 jam. Perendaman benih dalam air panas dengan suhu awal $60^{\circ} \mathrm{C}$ selama 72 jam menunjukan perlakukan terbaik untuk perkecambahan benih trembesi".

Faktor yang mempengaruhi keberhasilan perkecambahan benih trembesi adalah kesuburan media tanam, penggunaan pupuk dan cara penanaman. Kesuburan media yang baik untuk mendukung pertumbuhan dan perkembangan benih tergantung pada komposisi media tanam. Media tanam yang baik adalah media tanam yang porous sehingga akar dapat memperoleh udara dan air yang cukup, serta mampu menyediakan unsur-unsur hara yang diperlukan benih. Komposisi media tanam yang biasa digunakan adalah tanah, kompos dan pasir (Sumarna, 2002).

Menurut Setyati, 1987, "Benih yang berkeping dua muncul ke atas permukaan tanah, biasanya memerlukan penanaman yang lebih dangkal dari pada benih tunggal dalam tanah. Penanaman pada tanah yang relatif kering, harus dibuat lebih dalam". Lebih lanjut menurut Lita, 2004 "Dormasi benih terjadi karena benihnya bersifat dorman sehingga sulit berkecambah. Dormansi benih terjadi karena kulitnya yang keras dan kedap sehingga menjadi penghalang mekanis terhadap masuknya air dan gas ke dalam benih. Dormansi 


\section{JOURNAL OF FOREST SCIENCE AVICENNIA}

E-ISSN : 2622-8505 | Email : avicennia.kehutananumm@umm.ac.id hup://ejournal umm.ac.id/index.php/avicennia

O Jl. Raya Tlogomas No.246 Malang, Jawa Timur 0822-5785-2386 (Febri)

merupakan sifat alami benih untuk dapat bertahan hidup, tetapi sifat dormansi benih dapat menghambat produksi bibit dalam skala besar dan seragam. Untuk mengatasi dormansi benih pohon trembesi diperlukan skarifikasi. Skarifikasi bertujuan untuk melunakkan kulit benih yang keras, sehingga menjadi permeable terhadap air dan gas".

Pemecahan dormasi atau pematahan dormansi biasanya dilakukan dengan melakukan teknik skarifikasi dengan perendaman air panas. Menurut Zuhry, 2014 menjelaskan bahwa "Perlakuan perendaman dengan air panas bertujuan memudahkan penyerapan air oleh benih, caranya yaitu dengan memasukan benih ke dalam air panas dengan suhu awal $60^{\circ} \mathrm{C}$ dan perendaman air panas dengan suhu awal $100^{\circ} \mathrm{C}$ selama 5 menit dan dibiarkan sampai air menjadi dingin selama 24 jam"

\section{II.METODE PENELITIAN}

1. Waktu dan Tempat Penelitian

ini dilaksanakan pada bulan November 2018 - Februari 2019 dan dilaksanakan di screen house Jurusan Kehutanan Universitas Muhammadiyah Malang.

\section{Metode Pengambilan Data}

Metode pengambilan data penelitian kali ini menggunakan rancangan acak kelompok (RAK) yang disusun secara faktorial, yang terdiri dari dua faktor yaitu faktor pertama adalah perlakuan skarifikasi pada benih trembesi (A), sedangakan faktor kedua adalah komposisi media tanam (B).

\section{Peubah}

Peubah merupakan perhitungan pertumbuhan benih yang digunakan sebagai pembanding setiap perlakuan. Adapun peubah yang digunakan untuk mengamati perkecambahan dan pertumbuhan benih trembesi yaitu:

1. Daya perkecambahan, yang meliputi hidup dan mati. Pengamatan ini dilakukan dari benih mulai berkecambah sampai benih berumur 15 hari. Menurut Triwanto (2014) daya perkecambahan dapat dihitung dengan rumus sebagai berikut:

\section{Daya Kecambah (DK) \\ = jumlah benih yang berkecambah hingga akhir pengamatan + \\ benihy yano tidak tumbuh namun masih baik dan utuhn $\times 100 \%$ jumlah benih yang ditanam}

2. Laju perkecambahan benih dapat dihitung dengan cara menghitung dari jumlah hari benih berkecambah. Pengamatan ini dilakukan sejak benih ditaburkan sampai benih berumur 15 hari. Adapun rumusnya sebagai berikut:

Rata-rata hari $=\frac{\mathrm{N} 1 \mathrm{~T} 1+\mathrm{N} 2 \mathrm{~T} 2+\ldots+\mathrm{NxTX}}{\text { total benih yang berkecambah }}$

\section{Keterangan :}

$\mathrm{N}=$ jumlah benih yang berkecambah setiap hari

$\mathrm{T}=$ jumlah waktu antara awal pengujian sampai dengan akhir dari interval tertentu pengamatan

$X=$ (Triwanto 2014).

3. Pertumbuhan semai yang dilakukan setiap 7 hari 1 kali sampai berumur 60 hari, yang meliputi: 


\section{JOURNAL OF FOREST SCIENCE AVICENNIA}

E-ISSN : 2622-8505 | Email : avicennia.kehutananumm@umm.ac.id hup://ejournal umm.ac.id/index.php/avicennia

O Jl. Raya Tlogomas No.246 Malang, Jawa Timur 0822-5785-2386 (Febri)

(1) Tinggi tanaman, pengukuran ini dilakukan ketika benih berumur 16 hari dengan cara mengukur menggunakan penggaris dari pangkal batang sampai ujung batang.

(2) Jumlah daun, penghitungan jumlah daun ini dilakukan apabila benih sudah berkecambah dan muncul daun sejati yaitu pada umur 16 hari.

(3) Diameter batang, pengukuran ini dimulai sejak benih berumur 16 hari sampai umur 60 hari dengan menggunakan jangka sorong.

(4) Bobot basah dan bobot kering, pengukuran ini dilakukan pada akhir pengamatan setelah beumur 60 hari. Banyaknya semai yang diukur yaitu hanya 10 sampel dari 20 tanaman per kombinasi perlakuan.

(5) Panjang akar, pengukuran ini dilakukan setalah berumur 60 hari diukur mulai dari pangkal batang sampai dari akar yang terpanjang.

\section{Analisis Data}

Menurut Rochiman, 2008 bahwa model umum rancangan percobaan acak kelompok yang digunakan adalah :

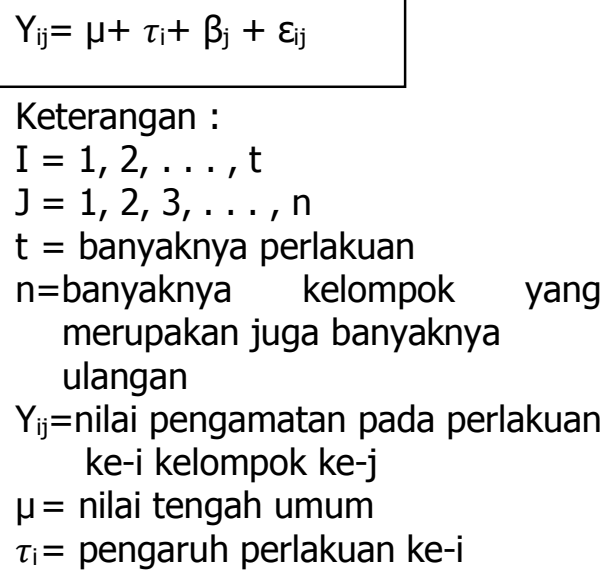

$\beta_{\mathrm{j}}=$ pengaruh perlakuan ke- $\mathrm{j}$

$\varepsilon_{\mathrm{ij}}=$ pengaruh acak pada perlakuan ke-i kelompok ke-j

Apabila hasil analisisnya berpengaruh nyata akan diuji lanjut menggunakan uji Duncan's p. 0,05.

\section{HASIL DAN PEMBAHASAN}

\section{Daya Kecambah}

Berdasarkan hasil analisa ragam menunjukkan bahwa terjadi interaksi yang sangat nyata antara perlakuan A (Skarifikasi) dengan B (komposisi media) terhadap daya kecambah benih trembesi (Samanea saman. Jacq). Untuk mengetahui perbedaan perlakuan yang terbaik dapat dilakukan uji lanjut Duncan'sp. 0,05 disajikan pada Tabel 1 .

Tabel 1 Rerata daya kecambah benih trembesi (S. saman. Jacq)

\begin{tabular}{rc}
\hline $\begin{array}{c}\text { Kombinasi } \\
\text { Perlakuan }\end{array}$ & $\begin{array}{c}\text { Rerata daya } \\
\text { kecambah }(\%)\end{array}$ \\
\hline A1B1 & $20,00 \mathrm{~b}$ \\
\hline A1B2 & $18,89 \mathrm{a}$ \\
\hline A1B3 & $16,66 \mathrm{a}$ \\
\hline A2B1 & $80,00 \mathrm{~b}$ \\
\hline A2B2 & $93,33 \mathrm{c}$ \\
\hline A2B3 & $96,66 \mathrm{~d}$ \\
\hline A3B1 & $82,22 \mathrm{c}$ \\
\hline A3B2 & $91,11 \mathrm{c}$ \\
\hline A3B3 & $95,55 \mathrm{~d}$ \\
\hline
\end{tabular}

Keterangan : Nilai rerata daya kecambah yang diikuti huruf yang sama pada kolom yang sama menunjukkan tidak berbeda nyata pada uji Duncan's p. 0,05.

Pada Tabel 1 menunjukkan bahwa kombinasi perlakuan A2B3 menghasilkan daya kecambah paling banyak 96,66\%, secara statistik tidak berbeda nyata dengan kombinasi perlakuan A3B3 $=95,55$ 


\section{JOURNAL OF FOREST SCIENCE AVICENNIA}

E-ISSN : 2622-8505 | Email : avicennia.kehutananumm@umm.ac.id hup://ejournal.umm.ac.id/index.php/avicennia

O Jl. Raya Tlogomas No.246 Malang, Jawa Timur 0822-5785-2386 (Febri)

\%, Namun berbeda dengan kombinasi perlakuan A1B3 paling sedikit yaitu, $16,66 \%$, secara statistik tidak berbeda nyata dengan kombinasi perlakuan $\mathrm{A} 1 \mathrm{~B} 2=$ $18,89 \%$, namun berbeda nyata dengan kombinasi perlakuan lainnya.

\section{Laju Kecambah}

Berdasarkan hasil dari analisa ragam menunjukkan tidak terjadi interaksi antara perlakuan A (skarifikasi) dengan B (komposisi media tanam) terhadap laju kecambah benih trembesi ( $S$. saman. Jacq) begitu juga dengan perlakuan lainya. Rerata laju perkecambahan benih dari perlakuan skarifikasi dan komposisi media dilanjut uji Duncan's p.0,05 disajikan pada Tabel 2.

Tabel 2 Rerata laju kecambah benih trembesi (S. saman. Jacq)

Keterangan : Nilai rerata laju kecambah yang diikuti huruf yang sama pada kolom yang sama menunjukkan tidak berbeda nyata pada uji Duncan's p. 0,05.

Pada Tabel 2 menunjukkan bahwa laju kecambah padaperlakuan A (skarifikasi) secara statistik cenderung paling cepat pada perlakuan $\mathrm{A} 1=7,53$ hari, sedangkan laju perkecambahan paling lambat pada perlakuan A3 = 7,97 hari, secara statistik tidak berbeda nyata dengan perlakuan $A 2$ $=7,67$ hari. Sedangkan perlakuan $B$ (komposisi media) kecenderungan paling cepat secara statistik pada perlakuan $\mathrm{B} 1=6,33$ hari, namun laju kecambah paling lambat perlakuan B2 $=8,47$ hari. Kedua perlakuan tersebut secara statistik tidak berbeda nyata dengan perlakuan B3 $=8,37$ hari.

\section{Jumlah Daun}

Berdasarkan hasil analisa ragammenunjukkan tidak terjadi interaksi antara perlakuan $A$ (skarifikasi) dengan B (komposisi media) terhadap pertambahan jumlah daun trembesi ( $S$. saman. Jacq). Namun perlakuan A (skarifikasi) pada minggu ketujuh dan ke delapan menunjukkan pengaruh sangat nyata pada pertambahan jumlah daun. Perlakuan B (komposisi media) menunjukkan pengaruh sangat nyata pada pertambahan jumlah daun pada minggu ke enam sampai

\begin{tabular}{cc}
\hline Perlakuan & $\begin{array}{c}\text { Rerata Laju } \\
\text { Kecambah } \\
\text { (Hari) }\end{array}$ \\
\hline A1 & $7,53 a$ \\
\hline A2 & $7,67 a$ \\
\hline A3 & $7,97 a$ \\
\hline B1 & \\
\hline B2 & $6,33 a$ \\
\hline B3 & $8,47 a$ \\
\hline
\end{tabular}

ke delapan. Untuk mengetahui hasil perlakuan A dan B dengan uji lanjut Duncan's p. 0.05 disajikan pada Tabel 3. 


\section{JOURNAL OF FOREST SCIENCE AVICENNIA}

E-ISSN : 2622-8505 | Email : avicennia.kehutananumm@umm.ac.id hup://ejournal.umm.ac.id/index.php/avicennia

Jl. Raya Tlogomas No.246 Malang, Jawa Timur 0822-5785-2386 (Febri)

Tabel 3. Rerata jumlah daun pada semai trembesi (S. saman. Jacq)

Perlakuan Rerata Jumlah Daun pada Berbagai Umur Pengamatan (MSS)

\begin{tabular}{ccccccccc} 
& 1 & 2 & 3 & 4 & 5 & 6 & 7 & 8 \\
\hline A1 & $8,87 a$ & $9,67 a$ & $11,13 a$ & $11,80 a$ & $12,73 a$ & $13,27 a$ & $14,53 c$ & $15,13 c$ \\
\hline A2 & $8,74 a$ & $9,50 a$ & $10,52 a$ & $11,06 a$ & $11,77 a$ & $12,55 a$ & $13,30 b$ & $13,72 a$ \\
\hline A3 & $8,79 a$ & $9,29 a$ & $10,32 a$ & $10,09 a$ & $11,75 a$ & $12,54 a$ & $13,17 a$ & $13,70 a$ \\
\hline & & & & & & & & \\
\hline B1 & $8,79 a$ & $9,37 a$ & $10,79 a$ & $11,51 a$ & $11,82 a$ & $12,24 a$ & $13,04 a$ & $13,38 a$ \\
\hline B2 & $8,68 a$ & $9,52 a$ & $10,63 a$ & $11,15 a$ & $11,89 a$ & $12,53 b$ & $13,38 b$ & $14,03 b$ \\
\hline B3 & $8,92 a$ & $9,57 a$ & $10,55 a$ & $11,19 a$ & $12,55 a$ & $13,59 b$ & $14,59 c$ & $15,15 c$ \\
\hline
\end{tabular}

Keterangan : Nilai rerata jumlah daun yang diikuti huruf yang sama pada kolom yang sama menunjukkan tidak berbeda nyata pada uji Duncan's p. 0,05.

Pada Tabel 3 menunjukkan perlakuan A (Skarifikasi) jumlah daun paling banyak pada perlakuan $A 1=15,13$ helai daun. Sedangkan jumlah daun paling sedikit pada perlakuan $A 3=13,70$ helai daun yang secara statistik tidak berbeda nyata dengan $A 2=13,72$ helai daun. Kemudian perlakuan B (komposisi media) menghasilkan jumlah daun paling banyak perlakuan B3 $=15,15$ helai daun, secara statistik berbeda nyata dengan perlakuan $B 2=14,03$ helai daun, dan $B 1=13,38$ helai daun lebih sedikit.

\section{Tinggi Tanaman}

Berdasarkan hasil analisa ragam menunjukkan tidak terjadi interaksi antara perlakuan A (skarifikasi) dengan B (komposisi media) terhadap tinggi tanaman trembesi (S. saman. Jacq) dari minggu kesatu sampai minggu ke delapan, Namun perlakuan $A$ berpengaruh nyata pada minggu kedelapan. Sedangkan perlakuan B tidak memberikan pengaruh terhadap tinggi tanaman trembesi ( $S$. saman. Jacq). Hasil perlakuan keduanya dapat dilanjut uji Duncan's p. 0.05 disajikan pada Tabel 4.

Tabel 4 Rerata tinggi semai trembesi (S. saman. Jacq)

\begin{tabular}{ccccccccc}
\multirow{2}{*}{ Perlakuan } & \multicolumn{7}{c}{ Rerata Tinggi Semai pada Beberapa Umur Pengamatan (MSS) } \\
\cline { 2 - 9 } & 1 & 2 & 3 & 4 & 5 & 6 & 7 & 8 \\
\hline A1 & $24,33 a$ & $25,13 a$ & $26,67 a$ & $27,33 a$ & $28,60 a$ & $28,73 a$ & $29,87 a$ & $30,47 c$ \\
\hline A2 & $22,03 a$ & $24,00 a$ & $24,99 a$ & $24,82 a$ & $27,24 a$ & $27,55 a$ & $28,06 a$ & $28,52 b$ \\
\hline A3 & $22,30 a$ & $22,83 a$ & $23,59 a$ & $24,59 a$ & $25,26 a$ & $26,04 a$ & $26,57 a$ & $26,95 a$ \\
\hline B1 & $23,74 a$ & $24,37 a$ & $25,53 a$ & $26,51 a$ & $27,80 a$ & $27,25 a$ & $27,93 a$ & $28,20 a$ \\
\hline B2 & $21,95 a$ & $22,83 a$ & $23,95 a$ & $24,42 a$ & $25,42 a$ & $25,86 a$ & $26,71 a$ & $27,35 a$ \\
\hline B3 & $22,97 a$ & $24,77 a$ & $25,77 a$ & $25,82 a$ & $27,88 a$ & $29,21 a$ & $29,86 a$ & $30,99 a$ \\
\hline
\end{tabular}

Keterangan : Nilai rerata tinggi tanaman yang diikuti huruf yang sama pada kolom yang sama menunjukkan tidak berbeda nyata pada uji Duncan's p. 0,05. 


\section{JOURNAL OF FOREST SCIENCE AVICENNIA}

E-ISSN : 2622-8505 | Email : avicennia.kehutananumm@umm.ac.id hup://ejournal umm.ac.id/index.php/avicennia

P Jl. Raya Tlogomas No.246 Malang, Jawa Timur 0822-5785-2386 (Febri)

Pada Tabel 4 menunjukkan perlakuan A (skarifikasi) tidak memberikan pengaruh pada tinggi tanaman trembesi dari minggu pertama sampai minggu ke tujuh, Namun minggu kedelapan perlakuan A memberikan pengaruh terhadap tinggi tanaman trembesi (S. saman. Jacq). Perlakuan A paling tinggi $\mathrm{A} 1=$ $30,47 \mathrm{~cm}$, secara statistik berbeda nyata dengan perlakuan $A 2=28,52$ $\mathrm{cm}$ dan $\mathrm{A} 3=26,95 \mathrm{~cm}$. Perlakuan $\mathrm{B}$ tidak menunjukkan pengaruh pada tinggi tanaman trembesi. Namun terdapat kecenderungan perlakuan paling tinggi $\mathrm{B} 3=30,99 \mathrm{~cm}$, sedangkan perlakuan paling pendek $\mathrm{B} 2=27,35 \mathrm{~cm}$ secara statistik tidak berbeda nyata dengan perlakuan $\mathrm{B} 1$ $=28,20 \mathrm{~cm}$.

\section{Diameter Batang}

Berdasarkan hasil analisa ragam menunjukkan tidak terjadi interaksi dan pengaruh antara perlakuan $A$ (skarifikasi) dengan B (komposisi media) terhadap diameter batang tanaman trembesi (S. saman. Jacq). Rerata diameter batang dari perlakuan A (skarifikasi) dan B (komposisi media) dilanjut uji Duncan's p. 0,05 disajikan pada Tabel 5.

Tabel 5. Rerata diameter batang trembesi (S. saman. Jacq)

\begin{tabular}{ccccccccc}
\hline \multirow{2}{*}{ Perlakuam } & \multicolumn{8}{c}{ Rerata Diameter Batang pada Beberapa Umur Pengamatan (MSS) } \\
\cline { 2 - 8 } & 1 & 2 & 3 & 4 & 5 & 6 & 7 & 8 \\
\hline A1 & $0,475 a$ & $0,475 a$ & $0,482 a$ & $0,482 a$ & $0,487 a$ & $0,487 a$ & $0,496 a$ & $0,496 a$ \\
\hline A2 & $0,475 a$ & $0,475 a$ & $0,481 a$ & $0,481 a$ & $0,486 a$ & $0,486 a$ & $0,491 a$ & $0,491 a$ \\
\hline A3 & $0,464 a$ & $0,464 a$ & $0,472 a$ & $0,472 a$ & $0,477 a$ & $0,477 a$ & $0,494 a$ & $0,494 a$ \\
\hline \multicolumn{1}{c}{} & & & & & & & \\
\hline B1 & $0,475 a$ & $0,475 a$ & $0,481 a$ & $0,481 a$ & $0,482 a$ & $0,482 a$ & $0,492 a$ & $0,492 a$ \\
\hline B2 & $0,463 a$ & $0,463 a$ & $0,471 a$ & $0,471 a$ & $0,475 a$ & $0,475 a$ & $0,486 a$ & $0,486 a$ \\
\hline B3 & $0,477 a$ & $0,477 a$ & $0,484 a$ & $0,484 a$ & $0,492 a$ & $0,492 a$ & $0,502 a$ & $0,502 a$ \\
\hline
\end{tabular}

Keterangan : Nilai rerata diameter batang yang diikuti huruf yang sama pada kolom yang sama menunjukkan tidak berbeda nyata pada uji Duncan's p. 0,05.

Pada Tabel 5 menunjukkan perlakuan A (skarifikasi) dan B (komposisi media) tidak memberikan pengaruh terhadap pertumbuhan diameter batang trembesi ( $S$. saman. Jacq). Namun perlakuan A (skarifikasi) paling besar diameter batang pada perlakuan $\mathrm{A} 1=0,496$ $\mathrm{cm}$, kemudian diameter batang paling kecil $A 2=0,491 \mathrm{~cm}$, secara statistik tidak berbeda nyata dengan perlakuan $\mathrm{A} 3=0,494 \mathrm{~cm}$. Perlakuan
B (komposisi media) diameter batang cenderung paling besar pada perlakuan B3 $=0,502 \mathrm{~cm}$, Secara statistik berbeda dengan prlakuan $\mathrm{B} 2=0,486 \mathrm{~cm}$ secara statistik tidak berbeda nyata dengan perlakuan $\mathrm{B} 1$ $=0,492 \mathrm{~cm}$ cenderung kecil.

\section{Panjang Akar}

Berdasarkan analisa ragam menunjukkan tidak terjadi interaksi antara perlakuan A (skarifikasi) dengan $B$ (komposisi media) 


\section{JOURNAL OF FOREST SCIENCE AVICENNIA}

E-ISSN : 2622-8505 | Email : avicennia.kehutananumm@umm.ac.id hup://ejournal.umm.ac.id/index.php/avicennia

O Jl. Raya Tlogomas No.246 Malang, Jawa Timur 0822-5785-2386 (Febri)

terhadap panjang akar tanaman trembesi ( $S$. saman. Jacq). Perlakuan A (skarifikasi) tidak berpengaruh terhadap panjang akar, Namun perlakuan B (komposisi media) berpengaruh sangat nyata terhadap panjang akar trembesi $(S$. saman. Jacq). Rerata panjang akar perlakuan A (skarifikasi) dan B (komposisi media) dilanjut uji Duncan's p. 0,05 disajikan pada Tabel 6.

Tabel 6 Rerata panjang akar trembesi (S. saman. Jacq).

\begin{tabular}{llc}
\hline $\begin{array}{l}\text { N} \text { Perlakuan } \\
\mathrm{i}\end{array}$ & $\begin{array}{c}\text { Rerata panjang akar } \\
(\mathrm{cm})\end{array}$ \\
\hline $\mathrm{I}$ & $\mathrm{A} 1$ & $20,60 \mathrm{a}$ \\
\hline $\mathrm{a}$ & $\mathrm{A} 2$ & $19,80 \mathrm{a}$ \\
$\mathrm{i}$ & $\mathrm{A} 3$ & $19,70 \mathrm{a}$ \\
\hline $\mathrm{K}$ & $\mathrm{B} 1$ & $17,37 \mathrm{a}$ \\
\hline $\mathrm{e}$ & $\mathrm{B} 2$ & $19,03 \mathrm{~b}$ \\
\hline $\mathrm{t}$ & $\mathrm{B} 3$ & $23,70 \mathrm{c}$ \\
\hline $\mathrm{e}$ & &
\end{tabular}

Keterangan : Nilai rerata panjang akar yang diikuti huruf yang sama pada kolom yang sama menunjukkan tidak berbeda nyata pada uji Duncan's p. 0,05.

Pada Tabel 6 menunjukkan perlakuan A (skarifikasi) tidak berpengaruh terhadap panjang akar. Namun akar paling panjang cenderung pada perlakuan $\mathrm{A} 1=$ $20,60 \mathrm{~cm}$. Perlakuan paling pendek A3 $=19,70 \mathrm{~cm}$, secara statistik tidak berbeda nyata dengan perlakuan $\mathrm{A} 2$ $=19,80 \mathrm{~cm}$.

Perlakuan B (komposisi media) menunjukkan pengaruh sangat nyata terhadap panjang akar. Perlakuan B (komposisi media) kecenderungan akar paling panjang pada perlakuan $\mathrm{B} 3=23,70 \mathrm{~cm}$. Akar yang paling pendek cenderung pada perlakuan $\mathrm{B} 1=17,37 \mathrm{~cm}$, secara statistik berbeda nyata dengan perlakuan $B 2=19,03 \mathrm{~cm}$.

\section{Bobot Basah dan Kering}

Berdasarkan analisa ragam menunjukkan tidak terjadi interaksi perlakuan A (skarifikasi) dengan B (komposisi media) terhadap bobot basah tanaman trembesi ( $S$. saman. Jacq). Namun perlakuam A (skarifikasi) berpengaruh sangat nyata terhadap bobot basah tanaman trembesi (S. saman. Jacq) sedangkan perlakuan B (komposisi media) tidak berpengaruh sangat nyata pada bobot basah tanaman trembesi ( $S$. saman. Jacq). Kemudian analisa pada lampiran $1 \mathrm{~h}$ menunjukkan tidak terjadi interaksi perlakuan A (skarifikasi) dengan $B$ (komposisi media) terhadap bobot kering tanaman trembesi (S. saman. Jacq). Namun perlakuam A (skarifikasi) berpengaruh sangat nyata terhadap bobot kering tanaman trembesi (S. saman. Jacq). Perlakuan B (komposisi media) tidak berpengaruh sangat nyata pada bobot kering tanaman trembesi ( $S$. saman. Jacq). Rerata perlakuan A (skarifikasi) dan B (komposisi media) dapat dilanjut uji Duncan's p. 0,05 disajikan pada Tabel 7. 


\section{JOURNAL OF FOREST SCIENCE AVICENNIA}

E-ISSN : 2622-8505 | Email : avicennia.kehutananumm@umm.ac.id hup://ejournal.umm.ac.id/index.php/avicennia

O Jl. Raya Tlogomas No.246 Malang, Jawa Timur 0822-5785-2386 (Febri)

Tabel 7. Rerata bobot basah dan kering tanaman trembesi ( $\mathcal{S}$. saman. Jacq).

\begin{tabular}{ccc}
\hline \multirow{2}{*}{ Perlakuan } & \multicolumn{2}{c}{$\begin{array}{c}\text { Rerata bobot basah dan } \\
\text { kering }\end{array}$} \\
\cline { 2 - 3 } & $\begin{array}{c}\text { Bobot } \\
\text { basah }\end{array}$ & Bobot kering \\
\hline A1 & $15,57 \mathrm{c}$ & $12,70 \mathrm{~b}$ \\
\hline A2 & $6,98 \mathrm{~b}$ & $4,44 \mathrm{a}$ \\
\hline A3 & $6,81 \mathrm{a}$ & $4,25 \mathrm{a}$ \\
\hline & & \\
\hline B1 & $9,41 \mathrm{a}$ & $7,11 \mathrm{a}$ \\
\hline B2 & $9,83 a$ & $7,16 \mathrm{a}$ \\
\hline B3 & $10,11 \mathrm{a}$ & $7,12 \mathrm{a}$ \\
\hline
\end{tabular}

Keterangan : Nilai rerata bobot basah dan kering yang diikuti huruf yang sama pada kolom yang sama menunjukkan tidak berbeda nyata pada uji Duncan's p. 0,05.

Pada Tabel 7 berat basah menunjukkan perlakuan A (skarifikasi) berpengaruh sangat nyata terhadap bobot basah tanaman, sehingga cenderung perlakuan paling berat $\mathrm{A} 1=15,57$ gram, Perlakuan paling ringan $\mathrm{A} 3=$ $6,81 \mathrm{~g}$, secara statistik tidak berbeda nyata dengan perlakuan $A 2=6,98$ gram. Perlakuan B (komposisi media) tidak berpengaruh nyata pada bobot basah. Namun terdapat kecenderungan perlakuan paling berat B3 $=10,11$ gramdan perlakuan paling ringan $B 1=9,41$ gram, secara statistik tidak berbeda nyata dengan perlakuan B2 $=9,83$ gram.

Pada Tabel 7 berat kering perlakuan A (skarifikasi) berpengaruh sangat nyata terhadap bobot kering tanaman. Dengan adanya pengaruh yang sangat nyata terhadap bobot kering maka terdapat perlakuan paling berat $\mathrm{A} 1$ $=12,70$ gram , perlakuan paling ringan $A 3=4,25$ gram, secara statistik tidak berbeda nyata dengan perlakuan $\mathrm{A} 2=4,44$ gram. Perlakuan B (komposisi media) tidak berpengaruh nyata pada bobot kering, namun perlakuan paling berat cenderung $\mathrm{B} 2=7,16$ gram, dan perlakuan paling ringan $\mathrm{B} 1=$ 7,11 gram, secara statistik tidak berbeda nyata dengan perlakuan B2 = 7,16 gram.

\section{PENUTUP}

\section{Kesimpulan}

Berdasarkan hasil penelitian yang sudah dilakukan untuk mengetahui pengaruh dari perlakuan skarifikasi dan komposisi media pada benih trembesi (Samanea saman. Jacq) dapat disimpulkan bahwa: Berdasarkan hasil analisa ragam pada lampiran 1 a terjadi interaksi sangat nyata antara kombinasi perlakuan A2B3 dengan daya kecambah paling banyak 96,66 \%. Perlakuan A2 perendaman air panas $80^{\circ} \mathrm{C}$ selama 24 jam merupakan perlakuan paling baik, jika waktu perendaman terlalu lama dapat merusak kulit benih, sehingga mengakibatkan lambat, cacat, dan bahkan kematian dalam proses berkecambah. Komposisi media paling baik B3 menggunakan tanah, pasir, pupuk kandang sapi.

\section{Saran}

Berdasakan penelitian yang dilaksanakan, penulis menyarankan untuk terus melakukan uji penelitian pada benih trembesi ( $S$. saman. Jacq) dengan perlakuan lainya seperti dengan perendaman gibberelin atau dengan perlakuan lainya dengan tujuan untuk mempercepat perkecambahan serta pertumbuhan dengan perlakuan 


\section{JOURNAL OF FOREST SCIENCE AVICENNIA}

E-ISSN : 2622-8505 | Email : avicennia.kehutananumm@umm.ac.id hup://ejournal.umm.ac.id/index.php/avicennia

O J1. Raya Tlogomas No.246 Malang, Jawa Timur 0822-5785-2386 (Febri)

yang terbaik mana yang cocok untuk benih trembesi.

\section{DAFTAR PUSTAKA}

Dahlan, E. (2010). Trembesi Dahulunya Asing namun Sekarang tidak lagi. Bogor: IPB Press.

Lubis, Y., Melya, R., \& Afif, B. (2014). Pengaruh Lama Waktu Perendaman dengan Air Terhadap Daya Berkecambah Trembesi (Samanea saman). Sylva Lest Vol 2, 25-32.
Sumarna, Y. (2002). Budidaya Jati. Jakarta: Penebar Swadaya.

Setyati. (1986). Pengantar Agronomi . Bogor: Departeman Agronomi Fakultas Pertanian IPB.

Zuhry, E. (2014). Teknologi Benih Kehutanan. Pekanbaru: Fakultas Prtanian Universitas Riau.

Triwanto, J. 2014. Petunjuk Praktikum Silvika. Laboraturium Kehutanan. Fakultas Pertanian dan Peternakan. Universitas Muhammadiyah Malang. Malang. 